\title{
Worker reproduction of the invasive yellow crazy ant Anoplolepis gracilipes
}

\author{
Ching-Chen Lee ${ }^{1,2}$, Hirotaka Nakao ${ }^{3}$, Shu-Ping Tseng ${ }^{4,5}$, Hung-Wei Hsu', Gwo-Li Lin ${ }^{4}$, Jia-Wei Tay 6 , Johan Billen7, \\ Fuminori Ito ${ }^{3}$, Chow-Yang Lee ${ }^{8 \dagger}$, Chung-Chi Lin ${ }^{1+}$ and Chin-Cheng (Scotty) Yang ${ }^{5^{*+}}$ (D)
}

\begin{abstract}
Background: Reproductive division of labor is one of the key features of social insects. Queens are adapted for reproduction while workers are adapted for foraging and colony maintenance. In many species, however, workers retain functional ovaries and can lay unfertilized male eggs or trophic eggs. Here we report for the first time on the occurrence of physogastric workers and apparent worker reproduction in the invasive yellow crazy ant Anoplolepis gracilipes (Fr. Smith). We further examined the reproductive potential and nutritional role of physogastric workers through multidisciplinary approaches including morphological characterization, laboratory manipulation, genetic analysis and behavioral observation.

Results: Egg production with two types of eggs, namely reproductive and trophic eggs, by physogastric workers was found. The reproductive egg was confirmed to be haploid and male-destined, suggesting that the workers produced males via arrhenotokous parthenogenesis as no spermatheca was discovered. Detailed observations suggested that larvae were mainly fed with trophic eggs. Along with consumption of trophic eggs by queens and other castes as part of their diet, the vital role of physogastric workers as "trophic specialist" is confirmed.

Conclusion: We propose that adaptive advantages derived from worker reproduction for $A$. gracilipes may include 1) trophic eggs provisioned by physogastric workers likely assist colonies of A. gracilipes in overcoming unfavorable conditions such as paucity of food during critical founding stage; 2) worker-produced males are fertile and thus might offer an inclusive fitness advantage for the doomed orphaned colony.
\end{abstract}

Keywords: Anoplolepis gracilipes, arrhenotokous parthenogenesis, physogastric workers, trophic eggs

\section{Background}

One of the hallmarks of higher social Hymenopterans (social bees, wasps, and ants) is the reproduction division of labor among nest members [1]. Queens are the reproductive caste that is morphologically adapted for dispersal and reproduction while workers are the non-reproductive caste specialized in foraging, nest maintenance and brood tending. A haplodiploid sex determination system is common to all hymenopterans, in which males arise parthenogenetically from unfertilized eggs (arrhenotoky) and are haploid, whereas females arise from fertilized eggs and are diploid $[2,3]$. Such unique system results in an asymmetrical genetic relatedness among the colony members where workers

\footnotetext{
* Correspondence: ccyang@rish.kyoto-u.ac.jp

${ }^{\dagger}$ Equal contributors

${ }^{5}$ Research Institute for Sustainable Humanosphere, Kyoto University, Gokasho,

Uji, Kyoto 611-0011, Japan

Full list of author information is available at the end of the article
}

are more genetically related to the queen's daughters (their sisters) $(r=0.75)$ compared to their own daughters and sons $(r=0.50)$ in a monogynous colony headed by a singly mated queen [4]. According to Hamilton's kin-selection theory, this unusual asymmetry in relatedness appears to favor evolution of a sterile worker caste as workers gain indirect fitness (i.e., propagation of their own genes) by behaving altruistically and assisting in raising the queen's instead of their own offspring.

Reproductive constraints impair the worker reproduction either through behavioral mechanisms (e.g., worker policing) or by suppressing the development of the reproductive organs in workers [5]. However, the workers in most ant species retain functional ovaries, and are capable of producing viable male eggs and/or non-viable trophic eggs [6]. Bourke [7] reported that workers produce males in approximately 50 species from 24 genera. Trophic eggs are nutritional packets, and act as an important mechanism 
for transferring nutrients or protein to the colony members, especially queens and larvae (reviewed in Wheeler [8]). Nevertheless, workers that have completely lost their reproductive organs only occur in a few genera (9 out of 283). These are Solenopsis, Monomorium, Tetramorium, Hypoponera, Anochetus, Leptogenys, Pheidole and Carebara $[1,9,10]$. It is interesting to note that in primitive ant species (e.g., Ponerinae), workers possess a spermatheca, and are capable of mating and produce fertilized eggs (i.e., gamergates) [11].

The yellow crazy ant Anoplolepis gracilipes has been listed as one of the world's top 100 invasive species due to their severe impacts on biological diversity and ecosystem sustainability [12]. This species is polygynous and forms supercolonies with individuals in physically separated colonies exhibiting limited aggression behavior towards each other [13]. A. gracilipes decimated over one-third of the entire population of endemic red crabs (Gecarcoidea natalis) in Christmas Island [14]. The displacement of native "keystone" species by this invasive ant indirectly impedes the litter breakdown process and causes the growth of sooty molds in canopy trees, which ultimately alters the island rainforest ecosystem. The numerical dominance of $A$. gracilipes negatively impacts the diversity and abundance of native invertebrate communities in introduced areas [15]. In addition, this species also attacks and kills populations of smaller vertebrates such as birds or new-born domestic animals, e.g. on the Seychelles [16-18].

So far, most of the well-studied invasive ants are known to possess a sterile worker caste [7], except for one previous study in which the presence of underdeveloped ovaries (i.e., absence of mature oocytes) was reported in a minority of $A$. gracilipes workers inspected [19]. While this study found little support for worker reproduction of A. gracilipes, our preliminary observation, in contrast, suggested that egg production often occurred in queenless $A$. gracilipes laboratory colonies, and that artificiallyorphaned colonies are invariably found with the presence of "corpulent" workers, whose gaster sizes were conspicuously greater than those of "normal" foraging workers and appeared brown-whitish in color (hereafter referred to as "physogastric workers"). Such morphological difference leads to a possible link between the egg production and presence of physogastric workers, and merits further investigation. In this study, we therefore conducted a series of experiments addressing the following questions: 1) are physogastric workers present in queenright field colonies? 2) what is the anatomy of the reproductive organs of physogastric workers? 3) can A. gracilipes workers produce viable and/or trophic eggs under queenless condition? 4) if viable eggs are produced, what is the sex and ploidy level of such worker-produced offspring? In addition to understand the fundamental aspects of worker reproduction by
A. gracilipes, the origin, trophic function and evolution of worker reproduction in this invasive ant species also are discussed.

\section{Results \\ Occurrence of physogastric workers and ovarian morphology of workers}

In all three field-collected colonies, $7.23-11.74 \%$ of the workers were physogastric. Gaster widths of normal workers (GW: $1.09 \pm 0.03 \mathrm{~mm}$, Fig. 1a) were significantly smaller than those of physogastric workers (GW: $1.53 \pm 0.02 \mathrm{~mm}$, Fig. $1 \mathrm{~b} ; \mathrm{Z}=-5.475, P<0.01$; Table 1 ). The clearly distinct external morphology of the queen is also illustrated in Fig. 1c.

We found normal workers possess ovaries, most of which, however, are underdeveloped and lacking of yolky oocytes (92\%) (Fig. 1d). Physogastric workers tend to possess more well-developed ovaries (Fig. 1e) as the number of ovarioles/individual is higher than in normal workers $(2.51 \pm 0.09$ vs. $1.62 \pm 0.12 ; Z=-5.652, P<0.01$; Table 1$)$, the number of yolky oocytes per ovariole (4.46 \pm 0.10 vs. $1.73 \pm 0.12 ; \mathrm{Z}=-10.416, P<0.01)$ and the total number of yolky oocytes were significantly higher in physogastric workers than in normal workers (11.21 \pm 0.48 vs. $2.81 \pm 0.31 ; Z=-8.290, P<0.01)$. Note that numbers presented here were based on those ovarioles with at least a visible oocyte only. While no spermatheca was found in both types of the workers, yellow bodies that are characteristic of reproduction were visible in some physogastric workers (13\%) (Fig. 1e). On average, queens of $A$. gracilipes had 44-52 ovarioles/individual and had a higher number of yolky oocytes $(94.50 \pm 6.63)$ than both types of workers. Yellow bodies were present in the ovaries of queens, along with a conspicuous spermatheca (Fig. 1f).

\section{External and internal morphology of workers}

Scanning electron microscopy revealed a noticeable difference in abdominal morphology between normal and physogastric workers (Fig. 2a and b). The abdomen of physogastric workers was greatly distended with exposed intersegmental membranes. Histological sections indicated that the fat body in the abdomen is far more abundant in physogastric than in normal workers (Fig. 2c and d). The absence of a spermatheca in physogastric workers was further confirmed by longitudinal histological sections (Fig. 2e), suggesting that sexual reproduction by workers of $A$. gracilipes is impossible.

\section{Production of eggs by workers, sex, ploidy level and morphology of worker-produced offspring}

After 4 months, we discovered that three out of nine artificially-orphaned colony fragments produced eggs and larvae, these three colonies fragments were designated as AGQLF01, AGQLF02 and AGQLF03. AGQLF01 was 


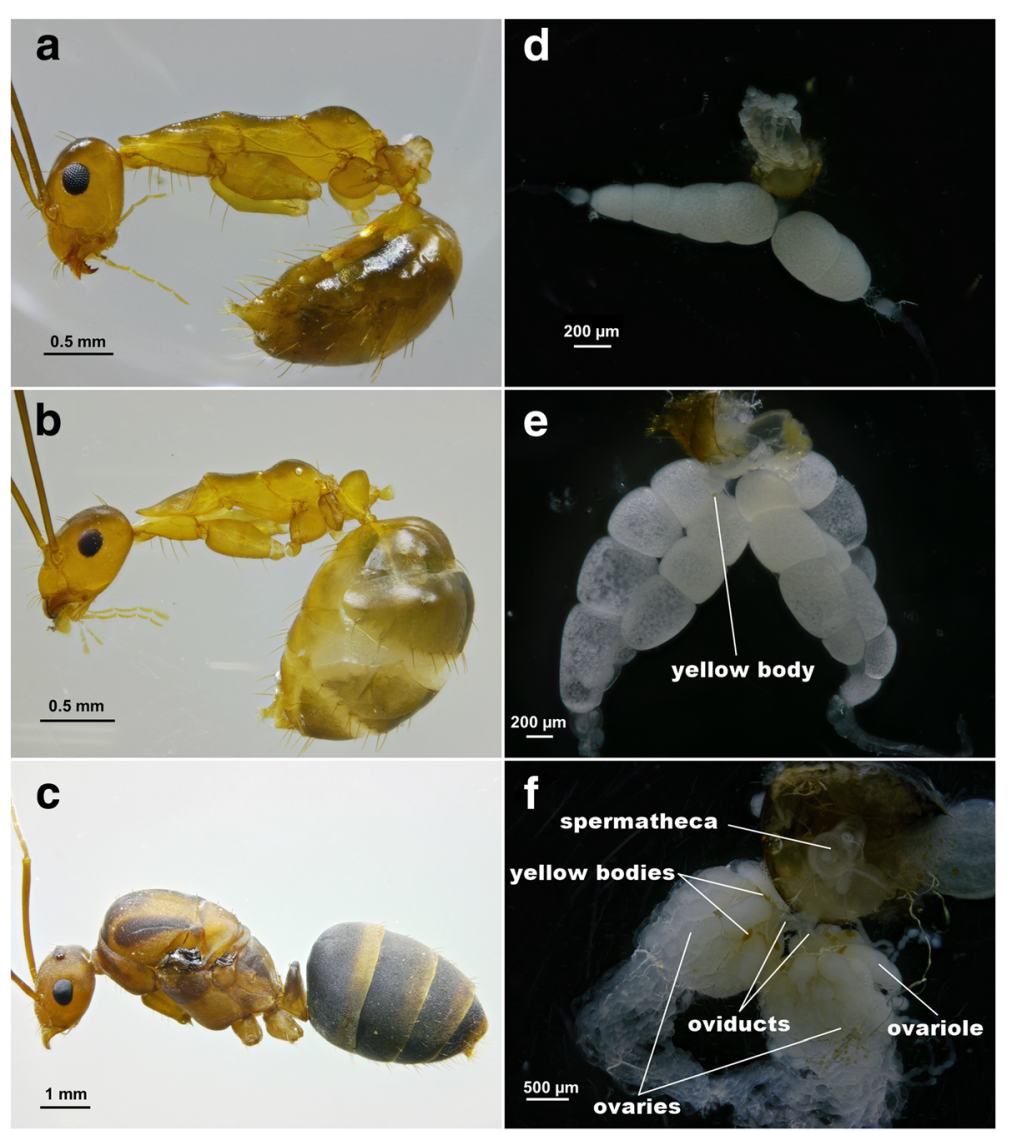

Fig. 1 Morphology and reproductive systems in worker and queen of A. gracilipes. Shown are the external morphology of normal worker (a), physogastric worker (b) and queen (c). Gaster dissection presenting ovarian morphology of normal worker (d), physogastric worker (e) and queen (f). Note difference in length of ovarioles and number of mature oocytes

isolated from the colony in Nantou County, while both AGQLF02 and AGQLF03 were isolated from the same source colony in Changhua County (Additional file 1: Figure S1). Morphological observations indicated the existence of two types of eggs produced by the workers, characteristically elongated oval shaped eggs and subspherically shaped eggs (Fig. 3). The former was confirmed viable with an obvious embryo, whereas the latter was embryoless and never hatched. Coupled with the fact that these non-viable eggs are consumed by larvae (Additional file 2: Video S1) and other castes (see "Fate of worker-laid trophic eggs" for more details), it is most likely that the eggs with sub-spherical shape serve as trophic eggs. Reproductive eggs in one (AGQLF03) of the three egg-producing colonies successfully developed into pupae that emerged as adult males $(n=18) 6$ months after the

Table 1 Differences in gaster size and ovary development across three castes of A. gracilipes

\begin{tabular}{|c|c|c|c|c|c|}
\hline Female castes & $\begin{array}{l}\text { Ants } \\
\text { dissected }\end{array}$ & Gaster width (mm) & $\begin{array}{l}\text { Number of ovarioles/ } \\
\text { individual }\end{array}$ & $\begin{array}{l}\text { Number of yolky oocytes per } \\
\text { ovariole }\end{array}$ & $\begin{array}{l}\text { Total number of yolky } \\
\text { oocytes }\end{array}$ \\
\hline Normal workers & $n=90$ & $\begin{array}{l}1.09 \pm 0.03[0.90- \\
1.30]\end{array}$ & $1.62 \pm 0.12[1-4]$ & $1.73 \pm 0.12[1-4]$ & $2.81 \pm 0.31[1-8]$ \\
\hline $\begin{array}{l}\text { Physogastric } \\
\text { workers }\end{array}$ & $n=90$ & $\begin{array}{l}1.53 \pm 0.02[1.40- \\
1.70]\end{array}$ & $2.51 \pm 0.09[2-5]$ & $4.46 \pm 0.10[1-9]$ & $11.21 \pm 0.48[6-27]$ \\
\hline Z & & -5.475 & -5.652 & -10.416 & -8.290 \\
\hline$P$ & & ${ }^{*}<0.01$ & $*<0.01$ & $*<0.01$ & $*<0.01$ \\
\hline Queens & $n=9$ & $\begin{array}{l}2.77 \pm 0.06[2.60- \\
3.00]\end{array}$ & $47.33 \pm 1.23[44-52]$ & $2.00 \pm 0.04[1-3]$ & $94.50 \pm 6.63[69-116]$ \\
\hline
\end{tabular}

Notes: Data are presented as mean \pm standard deviation [range]; * $p$, statistically significant using Mann-Whitney U-test; Queens were not subjected to analysis due to its small sample size 


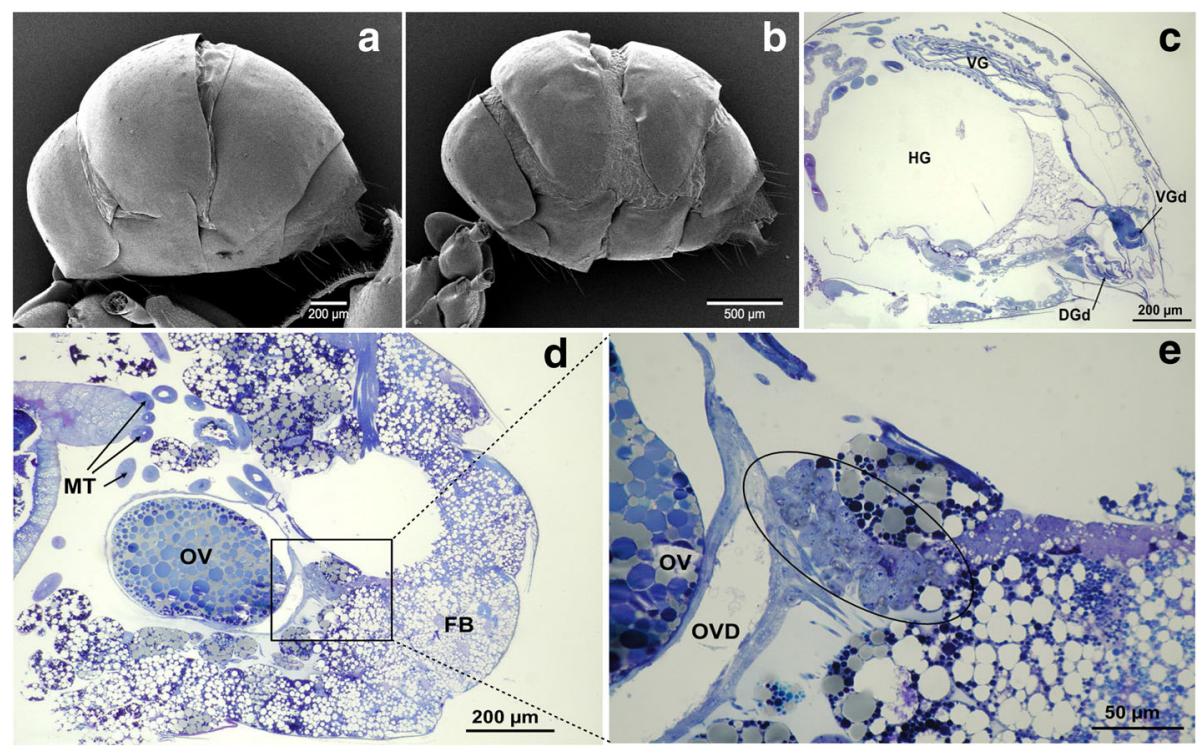

Fig. 2 Scanning electron micrographs and histological sections of two types of workers in A. gracilipes. SEMs of abdomen of normal worker (a) and physogastric worker (b), and longitudinal sections through posterior abdomen part of normal worker (c) and physogastric worker (d). Note large accumulation of fat body and absence of spermatheca in physogastric worker. The location where spermatheca is supposed to be found if it exists is highlighted with circled area in figure (e). DGd: Dufour gland duct, FB: fat body, HG: hindgut, MT: Malpighian tubules, OV: ovaries, OVD: oviduct, VG: venom gland, VGd: venom gland duct

start of the experiment, confirming the viability of the elongated oval shaped eggs. While larvae were present in AGQLF01 and AGQLF02 during the first 4 months, we failed to recover any adult male upon the end of the observation most likely due to cannibalism by nestmate (see Discussion).

Results of microsatellite genotyping revealed that all workers from AGQLF03 are heterozygotes across all loci with the presence of three major representing multi-locus genotypes (Table 2). Unlike the previously reported high frequency of heterozygous males $[19,20]$, we found that all

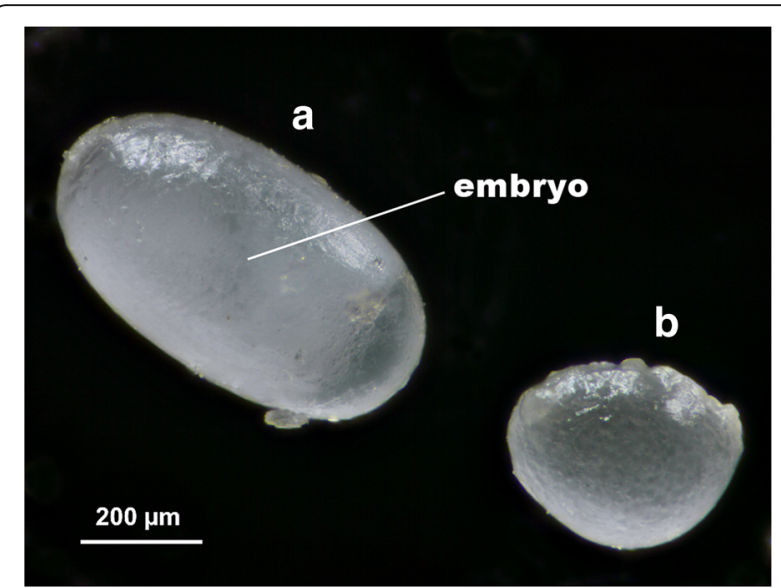

Fig. 3 Morphology of eggs produced by A. gracilipes workers. Light micrograph of a worker-laid reproductive egg (a) and a worker-laid trophic egg (b) males from AGQLF03 possess homozygous multi-locus genotypes, harboring one of the maternal alleles at all loci, which suggests that the worker-produced males are invariably haploid. In contrast, virtually all males (90\%) in the queenright colony (AGQR01) are diploid (heterozygous at least at one locus), a pattern consistent to previous studies that diploid males are common in the introduced ranges $[19,20]$.

Both head width and total body length of workerproduced male pupae (HW: $0.81 \pm 0.01 \mathrm{~mm}$; TL: $4.06 \pm 0.07 \mathrm{~mm}$ ) were significantly greater than those of queen-produced male pupae (HW: $0.70 \pm 0.01 \mathrm{~mm}$; TL: $3.69 \pm 0.05 \mathrm{~mm}$; Fig. 4a; HW: $\mathrm{Z}=-3.888, P<0.01$; TL: $\mathrm{Z}=-3.060, P<0.01)$. Similarly, the two measurements of worker-produced males (HW: $0.80 \pm 0.02 \mathrm{~mm}$; TL: $4.58 \pm 0.10 \mathrm{~mm}$ ) were also greater than those of queenproduced males, respectively (HW: $0.71 \pm 0.01 \mathrm{~mm}$; TL: $4.00 \pm 0.05$ mm; Fig. 4b; HW: $Z=-2.985, P<0.01$; TL: $\mathrm{Z}=-2.863, P<0.01)$. Worker-produced males, however, shared similar genital structures (Fig. 4c) and had similar internal reproductive organs (Fig. 4d) as adult males in a queenright colony. Rupturing of seminal vesicles in worker-produced males further showed the presence of viable sperm (i.e., sperm bundle with apparent swimming ability, Additional file 3: Video S2).

\section{Fate of worker-laid trophic eggs}

We tracked the fate of 62 and 51 trophic eggs produced by physogastric workers in colonies AGTE01 and AGTE02, respectively (Table 3). Visual observations 
Table 2 Genotypic distribution for individuals of various castes (queen, workers and males) from a queenright and queenless colony

\begin{tabular}{|c|c|c|c|c|c|c|c|c|c|c|c|c|c|c|c|}
\hline \multirow{2}{*}{\multicolumn{2}{|c|}{$\begin{array}{l}\text { Caste } \quad \text { Sample size } \\
\text { AGQR01 (queenright colon }\end{array}$}} & \multicolumn{2}{|l|}{ Anol } & \multicolumn{2}{|l|}{ Ano3 } & \multicolumn{2}{|c|}{ Ano4 } & \multicolumn{2}{|l|}{ Ano5 } & \multicolumn{2}{|l|}{ Ano6 } & \multicolumn{2}{|l|}{ Ano8 } & \multicolumn{2}{|c|}{ Ano10 } \\
\hline & & & & & & & & & & & & & & & \\
\hline Queen & 1 & 118 & & 168 & & 171 & & 139 & & 133 & & 232 & & 306 & \\
\hline Worker & 1 & 112 & 118 & 152 & 168 & 173 & 177 & 121 & 139 & 133 & 145 & 210 & 232 & 262 & 306 \\
\hline Worker & 2 & 112 & 118 & 152 & 178 & 171 & 177 & 121 & 135 & 133 & 145 & 210 & 232 & 262 & 306 \\
\hline Worker & 2 & 112 & 118 & 152 & 168 & 171 & 177 & 121 & 135 & 133 & 145 & 210 & 232 & 262 & 290 \\
\hline Worker & 3 & 112 & 118 & 152 & 168 & 171 & 177 & 121 & 135 & 133 & 145 & 212 & 234 & 262 & 308 \\
\hline Worker & 1 & 112 & 118 & 152 & 168 & 171 & 177 & 121 & 135 & 133 & 145 & 212 & 234 & 262 & 292 \\
\hline Worker & 3 & 112 & 118 & 152 & 178 & 173 & 177 & 121 & 135 & 133 & 145 & 210 & 232 & 262 & 306 \\
\hline Worker & 1 & 112 & 118 & 152 & 178 & 173 & 177 & 121 & 139 & 133 & 145 & 210 & 232 & 262 & 306 \\
\hline Worker & 1 & 112 & 118 & 152 & 178 & 173 & 177 & 121 & 135 & 133 & 145 & 212 & 234 & 262 & 308 \\
\hline Worker & 1 & 112 & 118 & 152 & 168 & 173 & 177 & 121 & 135 & 133 & 145 & 212 & 234 & 262 & 308 \\
\hline Male & 2 & 112 & 118 & 152 & 178 & 171 & 177 & 121 & 135 & 133 & 145 & 210 & 232 & 262 & 306 \\
\hline Male & 1 & 112 & 118 & 152 & 168 & 171 & 177 & 121 & 135 & 133 & 145 & 210 & 232 & -1 & -1 \\
\hline Male & 1 & 112 & 118 & 152 & 178 & 173 & 177 & 121 & 135 & 133 & 145 & 210 & 232 & 262 & 290 \\
\hline Male & 1 & 112 & 118 & 152 & 168 & 171 & 177 & 121 & 135 & 133 & 145 & 210 & 232 & 262 & 306 \\
\hline Male & 2 & 112 & 118 & 152 & 168 & 171 & 177 & 121 & 135 & 133 & 145 & 212 & 234 & 262 & 308 \\
\hline Male & 1 & 112 & 118 & 152 & 178 & 173 & 177 & 121 & 135 & 133 & 145 & 212 & 234 & 262 & 308 \\
\hline Male & 1 & 112 & 118 & 152 & 168 & 173 & 177 & 121 & 135 & 133 & 145 & 212 & 234 & 262 & 308 \\
\hline Male & 1 & 112 & 118 & 152 & 178 & 173 & 173 & 121 & 135 & 133 & 145 & 210 & 232 & 262 & 306 \\
\hline Male & 1 & 112 & 118 & 152 & 178 & 171 & 177 & 121 & 135 & 133 & 145 & 212 & 234 & -1 & -1 \\
\hline Male & 1 & 112 & 118 & 152 & 178 & 171 & 177 & 121 & 135 & -1 & -1 & 212 & 234 & 262 & 308 \\
\hline Male & 1 & 112 & 118 & 152 & 168 & 171 & 177 & 121 & 135 & -1 & -1 & 212 & 234 & 262 & 308 \\
\hline Male & 1 & 112 & 118 & 152 & 178 & 177 & 177 & 121 & 135 & 133 & 145 & 210 & 232 & 262 & 262 \\
\hline Male & 1 & 112 & 118 & 152 & 168 & 177 & 177 & 121 & 135 & 133 & 145 & 210 & 232 & -1 & -1 \\
\hline Male & 1 & 112 & 118 & 152 & 178 & 177 & 177 & 121 & 135 & 133 & 145 & 212 & 234 & 262 & 308 \\
\hline Male & 1 & 112 & 118 & 152 & 168 & 177 & 177 & 121 & 135 & 133 & 145 & 212 & 240 & 262 & 292 \\
\hline Male & 1 & 112 & 118 & 152 & 168 & 177 & 177 & -1 & -1 & 145 & 145 & 210 & 210 & -1 & -1 \\
\hline Male & 1 & 112 & & 152 & & 177 & & 121 & & 145 & & -1 & & 262 & \\
\hline Male & 1 & 112 & & 152 & & 177 & & 121 & & 145 & & 210 & & -1 & \\
\hline \multicolumn{16}{|c|}{ AGQLF03 (queenless colony fragment) } \\
\hline Worker & 4 & 112 & 118 & 152 & 168 & 171 & 177 & 121 & 139 & 133 & 145 & 212 & 212 & 262 & 290 \\
\hline Worker & 9 & 112 & 118 & 152 & 168 & 171 & 177 & 121 & 139 & 133 & 145 & 210 & 210 & 262 & 288 \\
\hline Worker & 1 & 112 & 118 & 152 & 168 & 171 & 177 & 121 & 139 & 133 & 145 & 210 & 210 & 262 & 290 \\
\hline Male & 1 & 118 & & 152 & & 171 & & 139 & & 133 & & -1 & & 290 & \\
\hline Male & 2 & 112 & & 168 & & 171 & & 121 & & 145 & & 212 & & 290 & \\
\hline Male & 1 & 118 & & 152 & & 177 & & 139 & & 145 & & -1 & & 292 & \\
\hline Male & 1 & 118 & & 168 & & 171 & & 121 & & 145 & & -1 & & 262 & \\
\hline Male & 1 & 118 & & 168 & & 171 & & 139 & & 145 & & 210 & & 288 & \\
\hline Male & 1 & 112 & & 168 & & 177 & & 139 & & 145 & & 210 & & 262 & \\
\hline Male & 1 & 112 & & 168 & & 177 & & 121 & & 145 & & 210 & & 290 & \\
\hline Male & 1 & 118 & & 168 & & 171 & & 121 & & 133 & & -1 & & 262 & \\
\hline Male & 1 & 118 & & 152 & & 177 & & 139 & & 133 & & -1 & & 288 & \\
\hline Male & 1 & 112 & & 168 & & 177 & & 139 & & 145 & & -1 & & 288 & \\
\hline
\end{tabular}


Table 2 Genotypic distribution for individuals of various castes (queen, workers and males) from a queenright and queenless colony (Continued)

\begin{tabular}{lllllllr}
\hline Male & 1 & 112 & 152 & 171 & 121 & 145 & -1 \\
Male & 1 & 118 & 168 & 177 & 121 & 133 & 290 \\
Male & 1 & 112 & 168 & 171 & 121 & 133 & 210 \\
\hline
\end{tabular}

-1 , amplification failure

indicated that most of the trophic eggs ( $\geq 63 \%$ ) were offered to the larvae. Coupled with the fact that larvae received occasional trophallaxis from workers and never directly fed on solid prey items during the entire observation period, trophic eggs appear to be the main food source for larvae in A. gracilipes. Queens received both liquid food via oral trophallaxis and trophic eggs from workers, and the former seems to be their main diet ( $\geq 89 \%$; Table 4$)$. We also discovered that trophic eggs were occasionally offered to other castes such as workers and males.

\section{Discussion}

We performed both field survey and laboratory manipulation to study worker reproduction in the invasive yellow crazy ant, A. gracilipes. The results of our survey confirm the existence of physogastric workers in the field colonies, and subsequent gaster dissection reveals that the level of ovarian development is significantly higher in physogastric than in normal workers. Workers in artificially orphaned colonies produced both trophic and viable (reproductive) eggs. The viable eggs from one of the queenless colonies successfully developed into
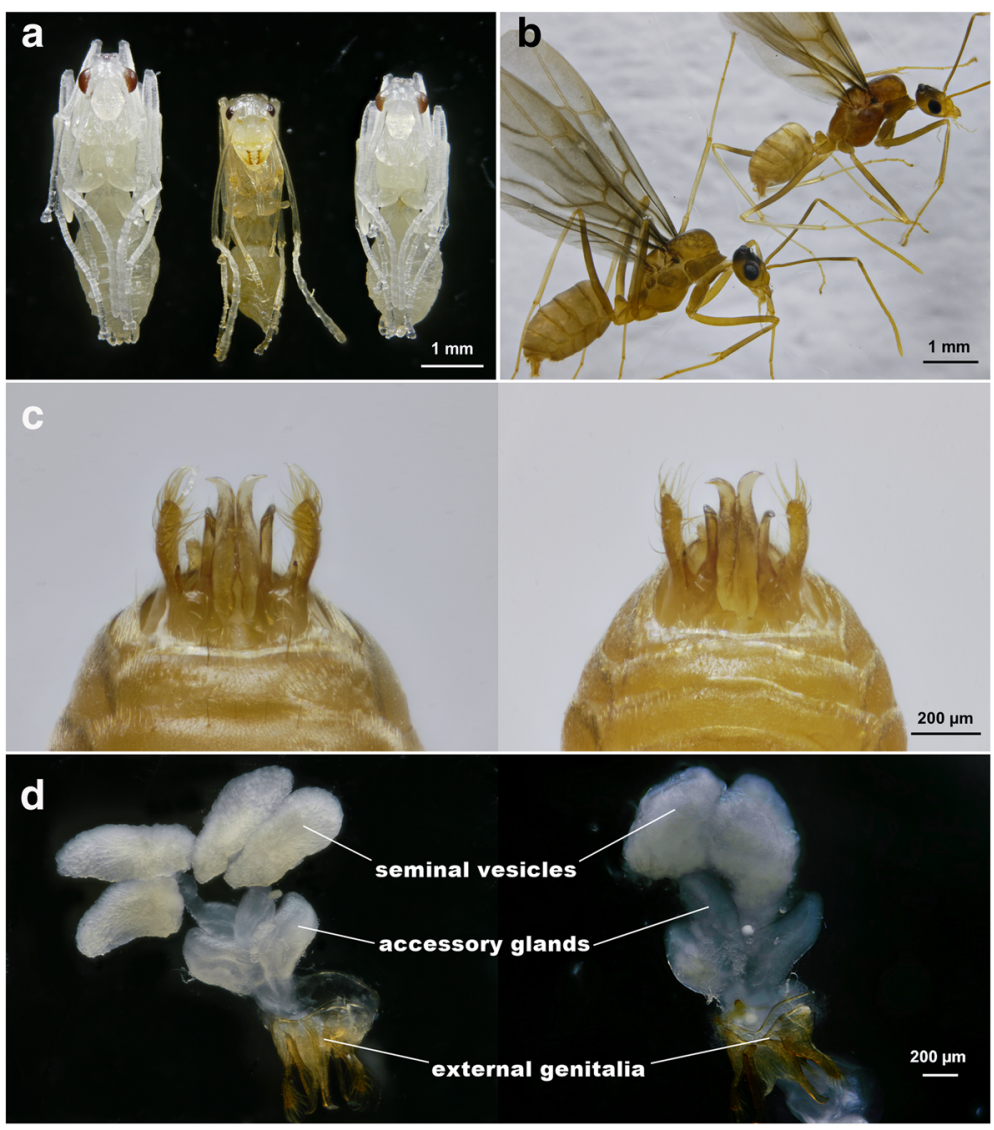

Fig. 4 Morphological comparison between worker-produced and queen-produced offspring in A. gracilipes. a Male pupa from orphaned colony (left), worker pupa (middle) and male pupa from queenright colony (right); (b) external morphology of worker-produced male (left) and normal queen-produced male (right); (c) close up of external genital structure of worker-produced male (left) and queen-produced male (right); (d) internal organs of the male reproductive system of worker-produced male (left) and queen-produced male (right) 
Table 3 The fate of worker-laid trophic eggs expressed by which caste/stage was a given trophic egg offered to after being laid

\begin{tabular}{|c|c|c|}
\hline & \multicolumn{2}{|c|}{ Colony code } \\
\hline & AGTE01 & AGTE02 \\
\hline Number of queens & 1 & 2 \\
\hline Number of workers & $\approx 900$ & $\approx 250$ \\
\hline Total hours of observation & 10.5 & 10 \\
\hline Total number of trophic eggs that had been followed & 62 & 51 \\
\hline \multicolumn{3}{|l|}{ Number of trophic eggs given to } \\
\hline dealate queens & $3(5 \%)$ & $4(8 \%)$ \\
\hline males & - & $8(15 \%)$ \\
\hline workers & $3(5 \%)$ & $1(2 \%)$ \\
\hline larvae & $56(90 \%)$ & $25(49 \%)$ \\
\hline queen larvae & - & $7(14 \%)$ \\
\hline Number of trophic eggs not given to any of particular caste mentioned above & - & $6(12 \%)$ \\
\hline
\end{tabular}

Notes: Values in parentheses refer to proportion of trophic eggs given to respective individuals or castes relative to the total number of trophic eggs that we tracked; Neither males nor queen larvae were found in colony AGTE01 during the observation

males that were slightly larger than those produced by queens. All worker-produced males were haploid and possess a normal, functional reproductive system as their diploid counterparts do. Furthermore, our data suggest that the production of trophic eggs plays a crucial role in regulating colony nutrition, especially for larvae. Below we discuss how these findings, combined with additional evidence obtained from histological, SEM and behavioral observation, provide new insights into the role of physogastric workers in A. gracilipes.

\section{Arrhenotokous parthenogenesis by physogastric workers} Our results clearly demonstrate that $A$. gracilipes workers are not functionally sterile, yet able to produce both trophic and reproductive eggs. In several ant species, workers are known for their ability to produce trophic eggs in queenright colonies and switch to produce reproductive eggs which develop into males once the queens die or disappear [21-23]. For instance, Aphaenogaster senilis workers produce unviable trophic eggs under queenright condition and begin to lay reproductive eggs that develop into males 4 months after being separated from the queens [24]. Similar to previous studies, our work showed that approximately 6 months after queen removal, some viable reproductive eggs successfully developed into adult males in one of the experimental $A$. gracilipes colony fragments. To the best of our knowledge, this is the first study showing that worker reproduction occurs in A. gracilipes.

While we lack direct evidence on whether workerproduced males can copulate with queens or female alates, their seemingly functional genitalia, intact reproductive organs and presence of viable sperm lead us to speculate that worker-produced males may have equal reproductive capacities as queen-produced males. It is thus plausible that in field conditions the last cohort of worker-produced males might be able to copulate with female alates from other colonies in the proximity, and subsequently offer fitness advantage to the doomed orphaned colony.

Previous studies have suggested that thelytokous parthenogenesis (i.e., diploid daughter females are produced from unfertilized eggs) may have occurred in A. gracilipes based on the finding of high intracolonial relatedness among workers [20, 25, 26]. In contrast, our microsatellite analyses suggested that worker-produced reproductive eggs are invariably haploid, instead of diploid as expected when thelytokous parthenogenesis

Table 4 Dietary composition (trophallaxis vs. consumption of trophic egg) of queens of $A$. gracilipes

\begin{tabular}{llll}
\hline & Colony code \& individual queen & & \\
\hline & AGTE01 Q1 & AGTE02 Q1 & AGTE02 Q2 \\
Total hours of observation & 10.5 & 10.5 & 10.5 \\
$\begin{array}{l}\text { Feeding on } \\
\text { liquid food via oral trophallaxis from workers }\end{array}$ & 324 times (89\%) & 74 times (97\%) & 60 times (92\%) \\
trophic eggs & 40 times (11\%) & 2 times (3\%) & 5 times (8\%) \\
\hline
\end{tabular}

Notes: Values in parentheses refer to frequency of consumption relative to the total number of feedings by queens; one whole trophic egg was consumed per feeding 
operates. We also showed that virtually all males in the queenright colony are diploid, which is consistent with previous studies in which a high prevalence of diploid males in A. gracilipes colonies was discovered [19, 20]. The high proportion of diploid males in the field colonies collected from this study and elsewhere may imply that in field conditions the haploid males are either rarely produced by workers when colonies remain queenright or are mostly consumed by nestmates as food resources. In general, mechanisms (e.g., queen repression, worker self-restraint and/or worker policing [27-30]) contributing to low or absence of worker reproduction in a queenright colony are predictable with sex ratio optimization, relatedness asymmetry and/or kin structure [31]. For example, Chapuisat et al. [32] found that male larvae of Formica exsecta are preferentially cannibalized by nestmate workers at their late developmental stage not only to regulate the sex ratio of colony but also to feed the females as additional food. We, however, note that the presence of an unusual reproduction mode (e.g., asexual production of the queen) and a high frequency of diploid males of A. gracilipes $[19,20]$ may not satisfy the prerequisites of such prediction (e.g., classic haplodiploidy), thus leading the interpretation of a favorable scenario extremely difficult. Yellow bodies were found in some of the physogastric workers from queenright colonies in this study, however, it remains questionable whether yellow bodies can be an appropriate indicator for oviposition of viable eggs as they are also visible in trophic egg layers for some species [33-35].

Furthermore, the body size of haploid males produced by workers is, on average, greater than that of the diploid counterparts produced by queens, and such finding is opposite to what has been reported for other ant species (e.g., Atta sexdens, Lasius sakagamii, Solenopsis invicta) whose diploid males tend to be bigger than haploid ones due to diploidization and feminization [3638]. Such inconsistency, however, might be explained by factors other than ploidy. Larger size and functional aspermy seem to be common feminized characteristics in diploid males of numerous hymenopterans [39]. The reproductive tracts in all diploid males of $A$. gracilipes we dissected, however, are fully functional with the presence of viable sperm, suggesting a negligible effect of ploidy level. We therefore regard the excess of food supply (to ensure worker survival since orphaned [40]) to the orphaned colony fragments or other factors such as social environment as an alternative contributing factor for the larger size of haploid males.

\section{Physogastric workers as trophic specialist}

Our observations have suggested that trophic eggs constitute a major dietary regime for larvae and approximately $11 \%$ of dietary regime in queens, suggesting physogastric workers that account for production of trophic eggs function as a trophic specialist in A. gracilipes colonies. At least three additional lines of evidence support such a nutritional role of the physogastric workers. First, while consumption of trophic eggs as main diet has been widely reported in ant species lacking the ability to share resources via trophallaxis [41], trophic eggs may hold as equal nutritional value in other trophallaxis-performing ant species [40, 42]. One plausible reason among is that trophic eggs serve as an essential food source for a specific caste and/or developmental stage in the colony $[8,43]$. Our data are in perfect agreement with such prediction as larvae of $A$. gracilipes appear to mainly consume trophic eggs during our entire observation period. Moreover, trophic eggs also are occasionally fed to queens, males and nestmate workers of $A$. gracilipes despite the presence of trophallaxis, further confirming that trophic eggs may serve as additional nutritional sources under some circumstances. Secondly, physogastric workers were found to occur together with younger brood and queens in the royal chamber (Additional file 2: Video S1, Additional file 4: Figure S2), and never engaged in foraging or other tasks outside the royal chamber. One may expect that trophic eggs, once produced, could be fed to the queen and larvae right away as they all stay within close proximity. This interpretation is further supported by our video showing that a trophic egg was fed to the adjacent brood pile immediately after it was laid by a physogastric worker (Additional file 2: Video S1).

The third line of evidence linked to the trophic function of physogastric workers is that the proportion of physogastric workers in the colony appears to be higher during fall and winter based on a preliminary field observation (CCLee et al., unpublished data). A. gracilipes is well-known for its broad diet as they prey on a variety of invertebrates as protein-rich food source (e.g., insects, small isopods and arachnids [16]). However, prey items of such kind cannot be stored easily as they are perishable, and its availability also fluctuates on a seasonal basis [43]. The high proportion of physogastric workers in the colony likely results in an increasing production of trophic eggs and thus represents an innate response of the colony to the declining availability of arthropod prey during such seasons [44]. We therefore suggest that the production of trophic eggs can be further regarded as an adaptive strategy for A. gracilipes, allowing colonies to sustain during unfavorable climatic conditions or periods of food shortage (e.g., winter) as trophic eggs can be stored for a longer period [45] and easily redistributed within the colony when needed.

\section{Evolution of worker production in A. gracilipes}

The presence of males in only one out of nine well-fed artificially-orphaned fragments suggests that male 
production by $A$. gracilipes workers after dequeening under field conditions appear to be uncommon. Such pattern might be explained by three mutually non-exclusive mechanisms: 1) If worker-laid trophic eggs are essential in terms of nutrient provision in the colony of A. gracilipes, selection may favor increased reproductive potential of worker castes (i.e., physogastric workers). Thus, the occasional emergence of worker-produced males could simply represent a by-product of the reproductive workers possessing highly-developed ovaries [40,41]. 2) Theoretically, each focal reproductive worker is expected to be more closely related to her own son than to the average workerproduced sons (nephews) [4]. Under this condition, kin selection theory predicts that potential conflict will arise among physogastric workers over male parentage as all physogastric workers are able to lay male eggs and will selectively remove work-laid brood (i.e., worker policing) to which they are less related [30, 46]. Nevertheless, extraordinarily high intracolony relatedness despite polygyny nature of $A$. gracilipes and unusual reproductive system [19, $20]$ indicate that worker-policing or competition for male parentage, if any, in this species possibly could not be explained by relatedness alone. 3) Aside from the relatedness hypothesis, low frequency of male production by workers in A. gracilipes may be attributed to selection for higher worker efficiency and colony-level productivity. An increasing number of studies have proposed that the cost of worker reproduction appears to underlie the regulation of worker policing and self-restraint in social insects [47, 48]. For instance, workers showed aggression behavior toward reproductive workers in the asexually reproducing ant, Platythyrea punctata where genetic conflicts are not expected as colony members are identical to each other due to clonality [49]. This is because reproductive workers invest less in non-reproductive tasks and hence may reduce the entire colony efficiency by disrupting the foraging activity or reducing life span in workers $[27,50,51]$. Similarly, it is highly possible that the male brood derived from workers in A. gracilipes is prevented from development by worker policing for optimizing priority task of physogastric workers, that is, the provisioning of nestmates with trophic eggs or other nursery-related tasks. Our data partially support this interpretation that male brood were found in all three viable egg producing colony fragments, but only one of which was observed with the presence of adult males.

\section{Conclusion}

Our study demonstrates for the first time that A. gracilipes workers possess functional ovaries and are able to produce both reproductive and trophic eggs. The former can be further developed into haploid males that may have equal reproductive fitness as their diploid counterparts, whereas the latter may have served as a critical regulator for protein-rich food (especially for larvae), thus allowing the colonies of $A$. gracilipes to survive through periods of food shortage. Furthermore, the current study offers an excellent chance to study if production of trophic eggs functions as an adaptive strategy for A. gracilipes when encountering food shortage, and how such behavior contributes to the success and ecological dominance of this ant as invasive species. We are currently generating the necessary baseline data to elucidate the ecological role of physogastric workers, factors that trigger ovary development of workers, the reproductive value of worker-produced males and how the combination of these mechanisms contributes to the invasiveness of this ant species.

\section{Methods}

\section{Existence of physogastric workers under natural conditions and reproductive organs of $A$. gracilipes workers}

Between December 2015 and February 2016, three queenright colonies of $A$. gracilipes were collected from Nantou (AGQR01), Changhua (AGQR02) and Miaoli (AGQR03) counties, Taiwan (Additional file 1: Figure S1), and brought to the lab for further inspection and experimental manipulations. Firstly, the presence of physogastric workers was visually inspected, and the percentage of physogastric workers in each colony was assessed. We define physogastric workers as workers whose gaster size is distinctly greater than that of normal foraging workers, and that appear brown-whitish in color. Thirty physogastric and thirty normal workers were randomly selected from each colony and dissected shortly after collection in the field (between 1 and 2 weeks). Prior to dissection, we measured gaster width (GW), maximum transverse distance across the gaster in dorsal view. Workers were anaesthetized with carbon dioxide followed by pulling of the last gastral tergite by forceps in PBS solution. Fat and tissue were removed to ease subsequent observation. To determine the ovarian development of workers (both physogastric and normal ones), the number of ovarioles/individual, number of mature or yolky oocytes per ovariole, and total number of yolky oocytes were counted for each worker inspected. As immature ovarioles are threadlike and difficult to visualize during dissection, we only focused on those ovarioles with at least one visible oocyte. The presence of yellow bodies and a spermatheca was also visually inspected in both types of workers. In addition, three queens per colony (a total of nine) were dissected to characterize the anatomical differences between queen and worker.

\section{SEM analysis and histology}

Physogastric and normal workers for scanning microscopy were critical point dried in a Balzers CPD 030 instrument, mounted on SEM-stubs, coated with gold, and examined in 
a JEOL JSM-6360 scanning microscope. To further confirm the presence of a spermatheca in both worker types, five physogastric and five normal workers were randomly selected from each colony (30 in total) mentioned above for histological sections. The posterior part of the gaster was cut off using microscissors and was fixed in cold $2 \%$ glutaraldehyde in a $50 \mathrm{mM} \mathrm{Na-cacodylate} \mathrm{buffer} \mathrm{at} \mathrm{pH} 7.3$ with $150 \mathrm{mM}$ saccharose. After postfixation in $2 \%$ osmium tetroxide in the same buffer and dehydration in a graded acetone series, tissues were embedded in Araldite. Serial longitudinal sections with a thickness of $2 \mu \mathrm{m}$ were made with a Leica EM UC6 ultramicrotome, stained with methylene blue and thionin and viewed in an Olympus BX-51 microscope. Voucher specimens were deposited in the Research Institute for Sustainable Humanosphere, Kyoto University, and are available upon request.

\section{Production of eggs in artificially-orphaned colonies}

A total of three colony fragments constituted of 100 randomly-selected normal workers were separated from each of the three original nests $(n=9)$. Caution was taken to avoid transfer of eggs and brood from the original colonies to ensure the presence of eggs in the colony fragment after isolation is the result of worker reproduction. Each colony fragment was cultured in a polyethylene container $(39 \times 31 \times 10 \mathrm{~cm})$ with its edges and inner surfaces coated with a thin layer of fluon to prevent escape of ants. Sugar water (10\%), crickets, and honeybee larvae were provided ad libitum. The experimental colony fragments were maintained under constant environmental conditions of $26 \pm 1{ }^{\circ} \mathrm{C}, 60 \pm 5 \%$ relative humidity and a 12 -h photoperiod. The egg and brood production were monitored ( 4 months) on a weekly basis, starting 4 weeks after colony fragmentation. If eggs were found, the morphology of the egg and eventual presence of an embryo were examined under a microscope. Some of the eggs were left uncollected and allowed to develop into pupa and adult stage if possible.

\section{Sex, ploidy level and morphology of worker-produced offspring}

If any worker-produced offspring was found at the end of the experimental period, both worker-produced offspring and several nestmate workers (randomly selected from the same colony fragment) were subjected to microsatellite genotyping. We genotyped a total of 14 worker-produced males and nestmate workers each from a queenless colony fragment (AGQLF03). To compare the genotypic distribution of individuals between queenright and queenless colony fragments, individuals of different castes including queen, workers and males from a queenright colony (AGQR01) were also genotyped. We genotyped a total of 15 workers and 20 males each from the queenright colony. Genomic DNA was extracted from tissue of each individual ant using the Gentra Puregene cell and tissue kit (Qiagen, USA) according to the manufacturer's instructions. Individual genotypes were assessed at seven nuclear microsatellite loci, including Ano1, Ano3, Ano4, Ano5, Ano6, Ano8 and Ano10, previously developed by Feldhaar et al. 2006 [52]. Microsatellite loci were amplified using the multiplex PCR method described by Blacket et al. 2012 [53]. The seven loci were amplified in two separate $15 \mu \mathrm{L}$ multiplex-PCRs, each containing three to four pairs of primers $(0.2 \mu \mathrm{M}), 0.2$ unit of SuperTherm Hot-start Taq DNA Polymerase (JMR Holdings, UK), $0.25 \mathrm{mM}$ of each dNTP, 1X SuperTherm Gold PCR buffer (JMR Holdings, UK), and 10$20 \mathrm{ng}$ of template DNA. Thermal cycling profiles were as follows: one cycle of $95^{\circ} \mathrm{C}(10 \mathrm{~min})$, followed by $35 \mathrm{cy}$ cles of $94{ }^{\circ} \mathrm{C} \quad(30 \mathrm{~s})$, primer-specific annealing temperature $55^{\circ} \mathrm{C}(30 \mathrm{~s})$, and $72{ }^{\circ} \mathrm{C}(30 \mathrm{~s})$, followed by a single final extension of $72{ }^{\circ} \mathrm{C}(30 \mathrm{~min})$. The resulting PCR products were analysed on an ABI-3730 Genetic Analyzer (Applied Biosystems) by Genomics BioSci \& Tech Co., Ltd. (Taipei, Taiwan). GeneMarker program (version 2.4.0, Softgenetics LLC) was employed to visualize and score alleles. Samples harboring homozygous multi-locus genotypes were considered haploid individuals, while those with heterozygote at one or more loci were considered diploid.

If any pupa or adult male successfully emerged in a worker-only colony fragment, both life stages were subjected to morphometric measurement. Pupa and male sizes were measured as head width (HW), maximum width of the head between the compound eyes and total body length (TL), and the total outstretched length from the mandibular apex to the gastral apex. The abovementioned measuring procedures were repeated on the individuals collected from queenright colony as reference.

\section{Fate of worker-laid trophic eggs}

A colony fragment composed by individuals from different castes was separated from each of the two original nests (AGQR01 \& AGQR02; $n=2$ ). Each colony fragment was maintained in a polypropylene container in which several transparent plastic boxes were inversely placed for housing ants as nest chambers [54]. The bottom of the container was filled with moistened plaster of Paris. These two colony fragments were designated as AGTE01 and AGTE02. A nest chamber was randomly selected for observation. Egg-laying workers or workers carrying trophic eggs were identified and observed for a total of $10.5 \mathrm{~h}$ ( 30 min observation period; $n=21$ ) and $10 \mathrm{~h}$ (30 min per observation period; $n=20$ ) in AGTE01 and AGTE02, respectively. More specifically, after a trophic egg was laid, we observed the fate of a given trophic egg as expressed by which caste a given trophic egg was offered to. As queens generally consumed 
trophic eggs much faster than other castes (Ito et al., unpublished data), we conducted a separate observation in which number of trophic eggs consumed by a given queen was recorded. Duration of observation was $10.5 \mathrm{~h}$ for each queen (30 min per observation period; $n=21$ ).

\section{Statistical analysis}

The gaster size and reproductive parameters (i.e., number of ovarioles/individual, number of yolky oocytes per ovarioles, and total number of yolky oocytes) between physogastric and normal workers were compared and analysed with Mann-Whitney $U$-test using SPSS version 16.0 (SPSS, Chicago, IL, USA) at $95 \%$ confidence interval. The same test was also applied to examine the morphometric differences between worker- and queen-produced offspring.

\section{Additional files}

Additional file 1: Figure S1. Map of Taiwan showing the collection sites of three queenright colonies (AGQR01-03) used in the current study. (TIFF $63 \mathrm{~kb}$ )

Additional file 2: Video S1. Fate of trophic eggs. A physogastric worker $\left(2^{\text {nd }}\right.$ worker in the upper left-hand corner) bends its gaster forward, seizes the freshly-laid egg with mandible and immediately offers the egg to an adjacent larvae pile. The video can be accessed through the URL https://www.youtube.com/watch?v=SvyrSZ-4n-s\&feature=youtu.be. (MOV 2973 kb)

Additional file 3: Video S2. Sperm bundles. Motile sperm bundles in the seminal vesicle of worker-produced males. The video can be accessed through the URL https:/wwww.youtube.com/watch?v=-AfHtSnak6A. (MOV 4352 kb)

Additional file 4: Figure S2. Physogastric workers in royal chamber. Physogastric workers were found tending younger brood (a) and form a dense retinue around the queen (b). (JPEG $14314 \mathrm{~kb}$ )

\section{Acknowledgements}

The authors would like to thank Po-Cheng Hsu for technical assistance. We also are very grateful to An Vandoren and Alex Vrijdaghs for their assistance in section preparation and scanning microscopy.

\section{Funding}

This study was financially supported through a Prospection Visit Grant of Leuven University (JB), the Ministry of Science and Technology, Taiwan (CCY), NTU Career Development Aid Grant (CCY) and the Future Development Funding Program of the Kyoto University Research Coordination Alliance (CCY).

\section{Availability of data and materials}

Data generated during this current study and necessary to interpret and build upon the findings are included in the published article and its additional files. Additional materials (ant samples, voucher specimens and videos) can be made available upon request.

\section{Authors' contributions}

CCL and CCY carried out the analyses and drafted the manuscript. CCLin, CCY and CYL planned and coordinated the study. CCL, HWH and JWT carried out the dissections and field collection of ants. Histology sections and SEM examination were done by JB. Observations on trophic eggs and queens' feeding behavior were performed by $\mathrm{HN}$ and Fl. Microsatellite analysis was done by SPT. The video fragments were filmed and prepared by GLL. All authors read, edited and approved the final version of the manuscript.

\section{Competing interests}

The authors declare that they have no competing interests.
Consent for publication

Not applicable

Ethics approval and consent to participate Not applicable

\section{Publisher's Note}

Springer Nature remains neutral with regard to jurisdictional claims in published maps and institutional affiliations.

\section{Author details}

'Department of Biology, National Changhua University of Education, No. 1, Jin-De Rd., Changhua 50007, Taiwan. ${ }^{2}$ Master Program for Plant Medicine, National Taiwan University, No.1, Sec. 4, Roosevelt Rd., Taipei, Taiwan106. ${ }^{3}$ Faculty of Agriculture, Kagawa University, Ikenobe, Miki 761-0795, Japan. ${ }^{4}$ Department of Entomology, National Taiwan University, No.1, Sec. 4, Roosevelt Rd., Taipei, Taiwan106. ${ }^{5}$ Research Institute for Sustainable Humanosphere, Kyoto University, Gokasho, Uji, Kyoto 611-0011, Japan. ${ }^{6}$ Department of Entomology, University of California, Riverside, CA 92521 , USA. ${ }^{7}$ K.U. Leuven, Zoological Institute, Naamsestraat 59, box 2466, B-3000 Leuven, Belgium. ${ }^{8}$ Urban Entomology Laboratory, Vector Control Research Unit, School of Biological Sciences, Universiti Sains Malaysia, 11800 Penang, Malaysia.

Received: 13 February 2017 Accepted: 26 April 2017

Published online: 08 May 2017

\section{References}

1. Wilson EO. The insect societies. Cambridge: Belknap Press of Harvard University Press; 1971.

2. Hamilton WD. The genetical evolution of social behaviour, I,II. J Theor Biol. 1964;7:1-52.

3. Hamilton WD. Altruism and related phenomena, mainly in social insects. Annu Rev Ecol Syst. 1972;3:193-232.

4. Bourke AFG, Franks NR. Social evolution in ants. Princeton: Princeton University Press; 1995.

5. Khila A, Abouheif E. Evaluating the role of reproductive constraints in ant social evolution. Phil Trans R Soc B. 2010;365:617-30.

6. Hölldobler B, Wilson EO. The ants. Cambridge: Harvard University Press; 1990.

7. Bourke AFG. Worker reproduction in the higher eusocial Hymenoptera. Q Rev Biol. 1988;63:291-311.

8. Wheeler DE. Nourishment in ants: patterns in individuals and societies. In: Hunt JH, Nalepa CA, editors. Nourishment and evolution in insect societies. Boulder: Westview; 1994. p. 245-78.

9. Oster G, Wilson EO. Caste and ecology in the social insects. Princeton: Princeton University Press; 1978.

10. Villet MH, Crewe RM, Duncan FD. Evolutionary trends in the reproductive biology of ponerine ants (Hymenoptera: Formicidae). J Nat Hist. 1991;25:1603-10.

11. Peeters C, Keller RA, Johnson RA. Selection against aerial dispersal in ants: two nonflying queen phenotypes in Pogonomyrmex laticeps. PLoS One. 2012;7:e47727.

12. Lowe S, Browne M, Boudjelas S, De Poorter M. 100 of the world's most invasive alien species: A selection from the global invasive species database. The Invasive Species Specialist group. http://rewilding.org/rewildit/images/ IUCN-GISP.pdf. Accessed Dec 2000.

13. Abbott KL. Supercolonies of the invasive yellow crazy ant, Anoplolepis gracilipes, on an oceanic island: Forager activity patterns, density and biomass. Insect Soc. 2005;52:266-73.

14. O'Dowd DJ, Green PT, Lake PS. Invasional 'meltdown' on an oceanic island. Ecol Lett. 2003;6:812-7.

15. Holway DA, Lach L, Suarez AV, Tsutsui ND, Case TJ. The causes and consequences of ant invasions. Annu Rev Ecol Syst. 2002;33:181-233.

16. Haines $I H$, Haines JB, Cherrett JM. The impact and control of the crazy ant, Anoplolepis gracilipes (Jerd.), in the Seychelles. In: Williams DF, editor. Exotic ants. Biology, impact and control of introduced species. Boulder: Westview Press; 1994. p. 206-19.

17. Hill M, Holm K, Vel T, Shah NJ, Matyot P. Impact of the introduced yellow crazy ant Anoplolepis gracilipes on Bird Island, Seychelles. Biodivers Conserv. 2003;12:1969-84.

18. Matsui S, Kikuchi T, Akatani K, Horie S, Takag M. Harmful effects of invasive yellow crazy ant Anoplolepis gracilipes on three land bird species of Minamidaito Island. Ornithological Sci. 2009;8:81-6. 
19. Gruber MAM, Hoffmann BD, Ritchie PA, Lester PJ. The conundrum of the yellow crazy ant (Anoplolepis gracilipes) reproductive mode: no evidence for dependent lineage genetic caste determination. Insect Soc. 2013;60:135-45.

20. Drescher J, Blüthgen N, Feldhaar H. Population structure and intraspecific aggression in the invasive ant species Anoplolepis gracilipes in Malaysian Borneo. Mol Ecol. 2007;16:1453-65.

21. Dietemann $V$, Peeters C. Queen influence on the shift from trophic to reproductive eggs laid by workers of the ponerine ant Pachycondyla apicalis. Insect Soc. 2000;47:223-8.

22. Gobin B, Peeters C, Billen J. Production of trophic eggs by virgin workers in the ponerine ant Gnamptogenys menadensis. Physiol Entomol. 1998;23:329-36.

23. Grangier J, Avril A, Lester PJ. Male production by workers in the polygynous ant Prolasius advenus. Insect Soc. 2013;60:303-8.

24. Ichinose K, Lenoir A. Reproductive conflict between laying workers in the ant Aphaenogaster senilis. J Ethol. 2009:27:475-81.

25. Gruber M, Hoffmann B, Ritchie P, Lester P. Crazy ant sex: genetic caste determination, clonality, and inbreeding in a population of invasive yellow crazy ants. In: Nash DR, den SPA B, Fine Licht HH, Boomsma JJ, editors. Copenhagen: XVI Congress of the International Union for the Study of Social Insects; 2010. p. 93.

26. Wenseleers T, Van Oystaeyen A. Unusual modes of reproduction in social insects: Shedding light on the evolutionary paradox of sex. BioEssays. 2011;33:927-37.

27. Cole BJ. The social behavior of Leptothorax allardycei (Hymenoptera: Formicidae): time budgets and the evolution of worker reproduction. Behav Ecol Sociobiol. 1986;18:165-73.

28. Endler A, Liebig J, Schmitt T, Parker JE, Jones GR, Schreier P, Hölldobler B. Surface hydrocarbons of queen eggs regulate worker reproduction in a social insect. Proc Natl Acad Sci U S A. 2004;101:2945-50.

29. Fletcher DJC, Ross KG. Regulation of reproduction in eusocial Hymenoptera. Annu Rev Entomol. 1985;30:319-43.

30. Ratnieks FLW. Reproductive harmony via mutual policing by workers in eusocial Hymenoptera. Am Nat. 1988;132:217-36.

31. Wenseleers T, Ratnieks FLW. Enforced altruism in insect societies. Nature. 2006:444:50

32. Chapuisat $M$, Sundström $L$, Keller $L$. Sex-ratio regulation: the economics of fratricide in ants. Proc R Soc Lond B. 1997;264:1255-60.

33. Billen JPJ. Ultrastructure of the workers ovarioles in Formica ants (Hymenoptera: Formicidae). Int J Insect Morphol Embryol. 1985;14:21-32.

34. Peeters C, Liebig J, Hölldobler B. Sexual reproduction by both queens and workers in the ponerine ant Harpegnathos saltator. Insect Soc. 2000;47:325-32.

35. Dietemann V, Hölldobler B, Peeters C. Caste specialization and differentiation in reproductive potential in the phylogenetically primitive ant Myrmecia gulosa. Insect Soc. 2002;49:289-98.

36. Armitage S, Boomsma JJ, Baer B. Diploid male production in a leaf-cutting ant. Ecol Entomol. 2010;35:175-82.

37. Ross KG, Fletcher DJC. Genetic origin of male diploidy in the fire ant Solenopsis invicta (Hymenoptera, Formicidae) and its evolutionary significance. Evolution. 1985:39:888-903.

38. Yamauchi K, Yoshida T, Ogawa T, Itoh S, Ogawa Y, Jimbo S, Imai HT. Spermatogenesis of diploid males in the formicine ant, Lasius sakagamii. Insect Soc. 2001;48:28-32.

39. Zayed A, Packer L. Complementary sex determination substantially increases extinction proneness of haplodiploid populations. Proc Natl Acad Sci U S A. 2005:102:10742-6.

40. Dijkstra MB, Boomsma JJ. Are workers of Atta leafcutter ants capable of reproduction? Insect Soc. 2006:53:136-40.

41. Smith CR, Schoenick C, Anderson KE, Gadau J, Suarez AV. Potential and realized reproduction by different worker castes in queen-less and queenright colonies of Pogonomyrmex badius. Insect Soc. 2007;54:260-7.

42. Heinze J, Cover SP, Hölldobler B. Neither worker, nor queen: an ant caste specialized in the production of unfertilized eggs. Psyche. 1995;102:173-85.

43. Crespi BJ. Cannibalism and trophic eggs in subsocial and eusocial insects. In: Elgar M, Crespi BJ, editors. Cannibalism: ecology and evolution among diverse taxa. Oxford: Oxford University Press; 1992. p. 176-213.

44. Bolger DT, Suarez AV, Crooks KR, Morrison SA, Case TJ. Arthropod in urban habitat fragments in southern California: area, age, and edge effects. Ecol Appl. 2000;10:1230-48.

45. Voss SH, Blum MS. Trophic and embryonated egg production in founding colonies of the fire ant Solenopsis invicta (Hymenoptera: Formicidae). Sociobiology. 1988;13:271-8.
46. Wenseleers T, Ratnieks FLW. Comparative analysis of worker reproduction and policing in eusocial Hymenoptera supports relatedness theory. Am Nat. 2006;168:E163-79.

47. Hammond RL, Bruford MW, Bourke AFG. Male parentage does not vary with colony kin structure in a multiple-queen ant. J Evol Biol. 2003;16:446-55.

48. Dijkstra MB, Boomsma JJ. The economy of worker reproduction in Acromyrmex leafcutter ants. Anim Behav. 2007;74:519-29.

49. Hartmann A, Wantia J, Torres JA, Heinze J. Worker policing without genetic conflicts in a clonal ant. Proc Natl Acad Sci U S A. 2003:100:12836-40.

50. Heinze J, Puchinger W, Hölldobler B. Worker reproduction and social hierarchies in Leptothorax ants. Anim Behav. 1997:54:849-64.

51. Tsuji K, Kikuta N, Kikuchi T. Determination of the cost of worker reproduction via diminished life span in the ant Diacamma sp. Evolution. 2012;66:1322-31.

52. Feldhaar $\mathrm{H}$, Drescher J, Blüthgen $\mathrm{N}$. Characterization of microsatellite markers for the invasive ant species Anoplolepis gracilipes. Mol Ecol Notes. 2006;6:912-4.

53. Blacket MJ, Robin C, Good RT, Lee SF, Milner AD. Universal primers for fluorescent labelling of PCR fragments-an efficient and cost-effective approach to genotyping by fluorescence. Mol Ecol Resour. 2012;12:456-63.

54. Ito F, Asfiya W, Kojima J. Discovery of independent-founding solitary queens in the yellow crazy ant Anoplolepis gracilipes in East Java, Indonesia (Hymenoptera: Formicidae). Entomol Sci. 2016;19:312-4.

\section{Submit your next manuscript to BioMed Central and we will help you at every step:}

- We accept pre-submission inquiries

- Our selector tool helps you to find the most relevant journal

- We provide round the clock customer support

- Convenient online submission

- Thorough peer review

- Inclusion in PubMed and all major indexing services

- Maximum visibility for your research

Submit your manuscript at www biomedcentral.com/submit
BioMed Central 